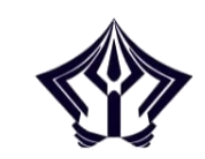

\title{
ANFUSINA: JOURNAL OF PSYCHOLOGY
}

http://ejournal.radenintan.ac.id/index.php/anfusina

DOI: //dx.doi.org/10.24042/ajp.v3i1.6891

Volume 3, Nomor 1, April Tahun 2020

\section{Pengaruh Integrative Behavioral Couple Therapy terhadap Pola Asuh Coparenting Orangtua}

\begin{tabular}{c}
\hline Nurul Fadhilah Khair \\
Program Studi Psikologi \\
Universitas Putra Indonesia "YPTK” Padang \\
nurulfadhilahkhair@upiyptk.ac.id \\
\hline
\end{tabular}

\begin{abstract}
Parents play an important role in the family, while the second role plays in parenting is very much needed by the child's development. Child's psychological development will be much better, if both require joint care or coparenting. The pattern of joint care or coparenting is mutual support and act as a team of mutual support, which is carried out by both parties. The main concept of coparenting care here is second, interconnected or mutually supportive in all forms of attitudes, relationships and teaching in parenting practices. This study uses a single case study design with $A-B-A$ model in which this research method is deemed suitable for the assessment of changes in therapy and applied therapy in couples. The results of the study showed a change in coparenting scores in each pair.
\end{abstract}

\begin{abstract}
Abstrak
Orangtua memegang peranan penting dalam keluarga, dimana peranan kedua orangtua dalam pola pengasuhan sangat dibutuhkan oleh perkembangan anak. Perkembangan anak secara psikologis akan menjadi jauh lebih baik, jika kedua orangtua menjalankan pengasuhan bersama atau coparenting. Pola pengasuhan bersama atau coparenting adalah sikap saling mendukung serta bertindak sebagai satu tim yang saling bekerjasama, yang dilakukan oleh kedua orangtua. Konsep utama dari pengasuhan coparenting disini adalah bahwa kedua orangtua, saling berhubungan atau saling sepakat dalam segala bentuk sikap, perilaku dan ajaran dalam praktik pengasuhan. Penelitian ini menggunakan desain penelitian single case dengan model A-B-A dimana metode penelitian
\end{abstract}


ini dirasa cocok untuk menilai perubahan perilaku dan terapannya dalam couple therapy. Perbedaan desain ini dengan desain penelitian lainnya yang menggunakan kelompok adalah dengan menggunakan jumlah $\mathrm{N}$ sedikit serta lebih menekankan pada perubahan individual. Hasil dari penelitian menunjukkan adanya perubahan skor coparenting pada setiap pasangan.

Keyword: integrative behavioral couple therapy, coparenting, dysfunctional parenting

\section{Pendahuluan}

Orangtua memegang peranan penting dalam keluarga, dimana peranan kedua orangtua dalam pola pengasuhan sangat dibutuhkan oleh perkembangan anak. Berdasarkan penelitian yang dilakukan terdahulu menyebutkan bahwa rendahnya keterlibatan salah satu atau kedua orangtua pada pola pengasuhan berdampak pada buruknya attachment antara orangtua dan anak (Bynion-Teah , et al. 2017, Flouri, Midouhas and Narayanan 2016) yang mengakibatkan munculnya simtom-simtom patologi dalam psikologi pada anak (Hugil, Fletcher and Berry 2017). Oleh karena itu, kehilangan salah satu atau kedua orangtua dalam praktik pengasuhan, akan beresiko terhadap munculnya gangguan psikologis tertentu pada anak.

Perkembangan anak secara psikologis akan menjadi jauh lebih baik, jika kedua orangtua menjalankan pengasuhan bersama atau coparenting. Pola pengasuhan bersama atau coparenting adalah sikap saling mendukung serta bertindak sebagai satu tim yang saling bekerjasama, yang dilakukan oleh kedua orangtua (Lestari 2012). Praktik coparenting oleh kedua orangtua, merupakan kolaborasi antara dua figur pengasuh yaitu Ayah dan Ibu dalam menjalankan tanggungjawab pengasuhan anak (Pudjibudojo, et al. 2019). Konsep utama dari pengasuhan coparenting disini adalah bahwa kedua orangtua, saling berhubungan atau saling sepakat dalam segala bentuk sikap, perilaku dan ajaran dalam praktik pengasuhan (Feinberg 2012).

Berdasarkan uraian di atas, disimpulkan bahwa penerapan pengasuhan coparenting antara kedua orangtua melibatkan kerjasama, sikap saling mendukung, berkolaborasi dalam sikap, perilaku dan pengajaran dalam pengasuhan. Aspek-aspek di atas, 
hanya akan terwujud jika hubungan antara kedua orangtua berjalan dengan baik dan harmonis. Hubungan romantis yang terjadi antara kedua orangtua, menjadi faktor penentu terciptanya dampak positif dalam praktik pengasuhan pada anak (Lavner, Barton and Beach 2019). Hubungan yang romantis antara kedua orangtua, diharapkan mampu memberikan cinta yang unconditional, nonjudgemental, dan everlasting kepada anak (Tifrere 2018). Hubungan kedua orangtua yang sehat disertai kepuasaan yang tinggi terhadap hubungan sebagai pasangan, dukungan, serta agreement mampu mengurangi konflik dalam praktik pengasuhan (McDaniel, et al. 2018).

Hubungan kedua orangtua yang tidak baik, mengakibatkan munculnya pola asuh yang disfungsional yang diterima oleh anak (Zhou 2016). Pola asuh kedua orangtua memiliki dampak tersendiri bagi perkembangan anak, dimana pola asuh ibu yang disfungsional membuat anak memiliki kesejahteraan psikologis rendah (Bynion-Teah , Blumenthal, Bilsky, Cloutier, \& LeenFledneer, 2017; Halldorsson \& Creswell, 2017; Ooi, Nocita, Coplan, Zhu, \& Rose-Krasnor, 2017), sedangkan keterlibatan Ayah yang rendah dalam pola pengasuhan akan membuat anak memiliki permasalahan sosial dalam tahap perkembangannya (Flouri, Midouhas and Narayanan 2016, Bynion-Teah, et al. 2017). Pola asuh disfungsional serta keterlibatan yang rendah dari kedua orangtua dalam pengasuhan akan memberikan dampak terhadap perkembangan psikologis serta sosial anak.

Bentuk pengasuhan disfungsional, yaitu: laxness atau disiplin yang lemah (permisif), overactive (authoritarian) serta verbosity (pola asuh mengomel) (Jackson and Dickinson 2009). Orangtua dengan tipe permisif cenderung memunculkan pola pengasuhan permisif dimana seringkali tidak menegakkan peraturan yang sudah disepakati, sering membiarkan anak berperilaku tidak tepat dan jarang sekali memberikan hukuman atas pelanggaran yang dilakukan anak (Papalia and Feldman 2014). Orantua tipe overreactive, cenderung menunjukkan ekspresi marah, mudah tersinggung, menunjuk hal-hal buruk pada diri anak, menuntut anak untuk patuh serta kurang hangat terhadap anak (Papalia and Feldman 2014). Sedangkan pola asuh verbosity adalah pola asuh orangtua yang seringkali memberikan kritik 
secara verbal serta banyak mengomel saat anak melakukan kesalahan (Fletcher, et al. 2009).

Konflik antara orangtua, maupun kurangnya keterlibatan salah satu orangtua dalam pengasuhan memiliki dampak negatif terhadap kelekatan emosional antara orangtua dengan anak (Bynion-Teah, et al. 2017, Flouri, Midouhas and Narayanan 2016). Kelekatan emosional yang tidak terjadi antara orangtua dan anak, dalam jangka panjang akan mengakibatkan berbagai permasalahan psikologis pada anak (Hugil, Fletcher and Berry 2017) salah satunya adalah gangguan kecemasan sosial atau social anxiety disorder (Brown 1999). Gangguan ini fokus pada ketakutan terhadap kondisi sosial apapun yang sering ditemuinya. Situasi sosial yang dekat dengan anak dan remaja adalah sekolah (Halldorsson and Creswell 2017, Kerig, Ludlow and Wenar 2012).

Bentuk ketakutan terhadap kondisi sekolah termanifestasi dalam bentuk perilaku takut masuk ke dalam kelas, takut menjawab pertanyaan atau melakukan presentasi di depan kelas, serta takut berinteraksi secara formal maupun informal dengan teman sebaya (Kearney 2005). Simtom ini sangat berbeda dengan gejala school fobia yang hanya menegaskan pada tidak adanya keinginan untuk pergi sekolah (Kerig, Ludlow and Wenar 2012) tanpa memiliki reaksi lain seperti ketakutan yang sangat besar untuk terlibat dalam lingkungan sosial sekolah (Eroglu S. 2012, Ooi, et al. 2017). Perbedaan lainnya adalah pada reaksi fisiologis berupa jantung berdetak kencang, berkeringat sesak nafas dan perubahan lainnya yang terkadang mengiringi individu dengan social anxiety disorder (American Psychiatric Assocation 2013).

Gangguan psikologis di atas, bisa dihindari jika kedua orangtua memperbaiki hubungan yang bermasalah dengan teknik terapi pasangan (couple therapy). Terapi pasangan atau couple therapy merupakan treatment yang efektif dalam melepaskan stress dan menyelesaikan konflik antar pasangan (Hewison, Casey and Mwamba 2016). Teknik terapi yang dilakukan pada intervensi ini adalah, integrative behavioral couple therapy yaitu terapi yang berfokus pada pandangan individu mengenai kepuasannya terhadap hubungan, dan mengenal emosi mereka masing-masing. Tahapan dalam terapi ini adalah evaluasi dan treatment (acceptance-focused strategies \& change-focused strategies) (Lebow 2005). Kedua orangtua diajak untuk menyelesaikan 
konfliknya masing-masing kemudian bekerjasama dalam memberikan dukungan kepada anak.

\section{Metode Penelitian}

Penelitian ini menggunakan desain penelitian single case dengan model A-B-A (Perone and Hursh 2005, Sunanto, Takeuchi and Hideo 2005), dimana metode penelitian ini dirasa cocok untuk menilai perubahan perilaku dan terapannya dalam couple therapy (Sprenkle and Piercy 2005). Metode pengumpulan data mengacu kepada pengulangan pengukuran dalam tiga fase, yaitu fase $\mathrm{A}$ merupakan pengukuran sebelum dilakukan intervensi, fase B merupakan fase pengulangan pengukuran pada saat diberikan intervensi, dan kembali pada fase A yang merupakan fase pengukuran setelah intervensi. Perbedaan desain ini dengan desain yang menggunakan kelompok adalah dengan menggunakan jumlah $\mathrm{N}$ sedikit serta lebih menekankan pada perubahan individual (Sunanto, Takeuchi and Hideo 2005).

Metode analisis dan interpretasi data yang dilakukan dalam penelitian ini adalah inspeksi visual (visual inspection), dimana analisis ini secara umum digunakan dalam penelitian subyek tunggal (single case) (Barker, et al. 2011). Penelitian dengan subjek tunggal merupakan penelitian yang dilakukan dengan subjek yang sedikit jumlahnya (Sunanto, Takeuchi and Hideo 2005). Pengukuran di dalam penelitian ini dilakukan dengan perbandingan antara alat ukur.

Analisis data visual dalam penelitian ini menggunakan empat teknik, yaitu:

1. Rerata, yaitu rerata data/skor yang diperoleh dalam masingmasing fase atau kondisi baik pada saat sebelum perlakuan diberikan (pre-test), setelah perlakuan diberikan (post-test)

2. Tingkat stabilitas, yaitu menunjukkan derajat variasi atau besar kecilnya rentang data yang dimiliki oleh kelompok data tertentu. Jika 80 hingga $90 \%$ data secara umum masih berada pada $15 \%$ diatas dan dibawah rerata, maka data tersebut sudah dapat dikatakan stabil (Sunanto, Takeuchi and Hideo 2005).

3. Perubahan level, pada fase ini perubahan terdiri dari:

a. Perubahan level dalam kondisi, didapatkan dengan cara menentukan besaran data poin (skor) pertama dan terakhir 
dalam suatu kondisi kemudian mengurangi data yang besar dengan yang kecil.

b. Perubahan level antar kondisi, didapatkan dengan cara menentukan data poin (skor) terakhir pada kondisi pertama, kemudian menentukan data point (skor) terakhir pada kondisi kedua, kemudian mengurangi data point yang besar dengan yang kecil.

4. Kecenderungan arah grafik (trend/slop) yaitu menunjukkan perubahan setiap data dari setiap sesi (waktu ke waktu) apakah meningkat, mendatar atau menurun. Masing-masing maknanya tergantung pada tujuan intervensi. (Sunanto , Takeuchi and Hideo 2005).

Baik perubahan level dalam kondisi maupun perubahan level antar kondisi dapat ditentukan apakah perubahan tersebut menunjukkan arah yang membaik (therapeutic) atau memburuk (contratherapeutic) sesuai dengan tujuan intervensi atau perlakuan yang diberikan (Sunanto, Takeuchi and Hideo 2005). 


\section{Hasil dan Pembahasan}

Partisipan dalam penelitian ini berjumlah 4 pasangan. Berikut latar belakang partisipan yang dilibatkan dalam penelitian ini.

\section{Tabel 1.}

Partisipan penelitian

\begin{tabular}{|c|c|c|c|}
\hline Inisial & Usia & Pekerjaan & keterangan \\
\hline AM (Suami) & 43 tahun & Swasta & \\
\hline $\begin{array}{c}\text { MR } \\
\text { (Istri) }\end{array}$ & 39 tahun & $\begin{array}{c}\text { Ibu } \\
\text { Rumah } \\
\text { Tangga }\end{array}$ & \\
\hline BW (suami) & 48 tahun & PNS & \\
\hline $\begin{array}{c}\mathrm{PH} \\
\text { (istri) }\end{array}$ & 40 tahun & Guru & \\
\hline SU (suami) & 49 tahun & $\begin{array}{c}\text { Karyawan } \\
\text { Swasta }\end{array}$ & \\
\hline MU (istri) & 49 tahun & $\begin{array}{c}\text { Ibu } \\
\text { Rumah } \\
\text { Tangga }\end{array}$ & \\
\hline LH (suami) & 50 tahun & PNS & \\
\hline NR (istri) & 47 tahun & $\begin{array}{l}\text { Ibu rumah } \\
\text { tangga }\end{array}$ & \\
\hline
\end{tabular}




\section{Tabel 2.}

Uraian skor skala coparenting

\begin{tabular}{|c|c|c|c|}
\hline $\begin{array}{c}\text { Analisis } \\
\text { Visual }\end{array}$ & Pre-test (A1) & Post-test (B) & Follow-up (A2) \\
\hline \multicolumn{4}{|c|}{ Pasangan 1} \\
\hline Rerata & 169.4 & 173.2 & 99 \\
\hline Tingkat & $100 \%$ & $100 \%$ & $20 \%$ \\
\hline Stabilitas & (stabil) & (stabil) & (tidak stabil) \\
\hline $\begin{array}{l}\text { Perubahan } \\
\text { level } \\
\text { (dalam fase) }\end{array}$ & $\begin{array}{c}171-168=3 \\
\text { (memburuk) }\end{array}$ & $\begin{array}{c}171-177=-6 \\
\text { (membaik) }\end{array}$ & $\begin{array}{c}88-112=-24 \\
\text { (membaik) }\end{array}$ \\
\hline $\begin{array}{l}\text { Perubahan } \\
\text { level } \\
\text { (antar fase) }\end{array}$ & \multicolumn{3}{|c|}{$\begin{array}{l}\text { Skor awal B }- \text { skor akhir A1 : } 177-171=6 \\
\text { (memburuk) } \\
\text { Skor awal A2 - Skor Akhir B : } 112-171=-59 \\
\text { (membaik) }\end{array}$} \\
\hline \multicolumn{4}{|l|}{$\begin{array}{l}\text { Kecenderungan } \\
\text { arah grafik } \\
\text { (trend/slope) }\end{array}$} \\
\hline Arah & Naik & Turun & Turun \\
\hline \multicolumn{4}{|c|}{ Pasangan 2} \\
\hline Rerata & 32.3 & 31.8 & 22 \\
\hline $\begin{array}{l}\text { Tingkat } \\
\text { Stabilitas }\end{array}$ & $\begin{array}{c}90 \% \\
\text { (stabil) }\end{array}$ & $\begin{array}{c}0 \% \\
\text { (tidak stabil) }\end{array}$ & $\begin{array}{c}100 \% \\
\text { (stabil) }\end{array}$ \\
\hline $\begin{array}{l}\text { Perubahan } \\
\text { level } \\
\text { (dalam fase) }\end{array}$ & $\begin{array}{c}35-31=4 \\
(\mathrm{MEMBURU} \\
\mathrm{K})\end{array}$ & $\begin{array}{c}22-43=-21 \\
(\text { MEMBAIK) }\end{array}$ & $\begin{array}{l}22-22=0 \\
\text { (Tetap) }\end{array}$ \\
\hline $\begin{array}{l}\text { Perubahan } \\
\text { level } \\
\text { (antar fase) }\end{array}$ & \multicolumn{3}{|c|}{$\begin{array}{c}\begin{array}{c}\text { Skor awal B }- \\
\text { skor akhir A1 : } 43-35=8 \\
\text { (memburuk) }\end{array} \\
\text { Skor awal A2 }- \text { Skor Akhir B : } 22-22=0 \text { (tetap) }\end{array}$} \\
\hline $\begin{array}{l}\text { Kecenderungan } \\
\text { arah grafik } \\
\text { (trend/slope) }\end{array}$ & & & \\
\hline Arah & Naik & Turun & Tetap \\
\hline
\end{tabular}




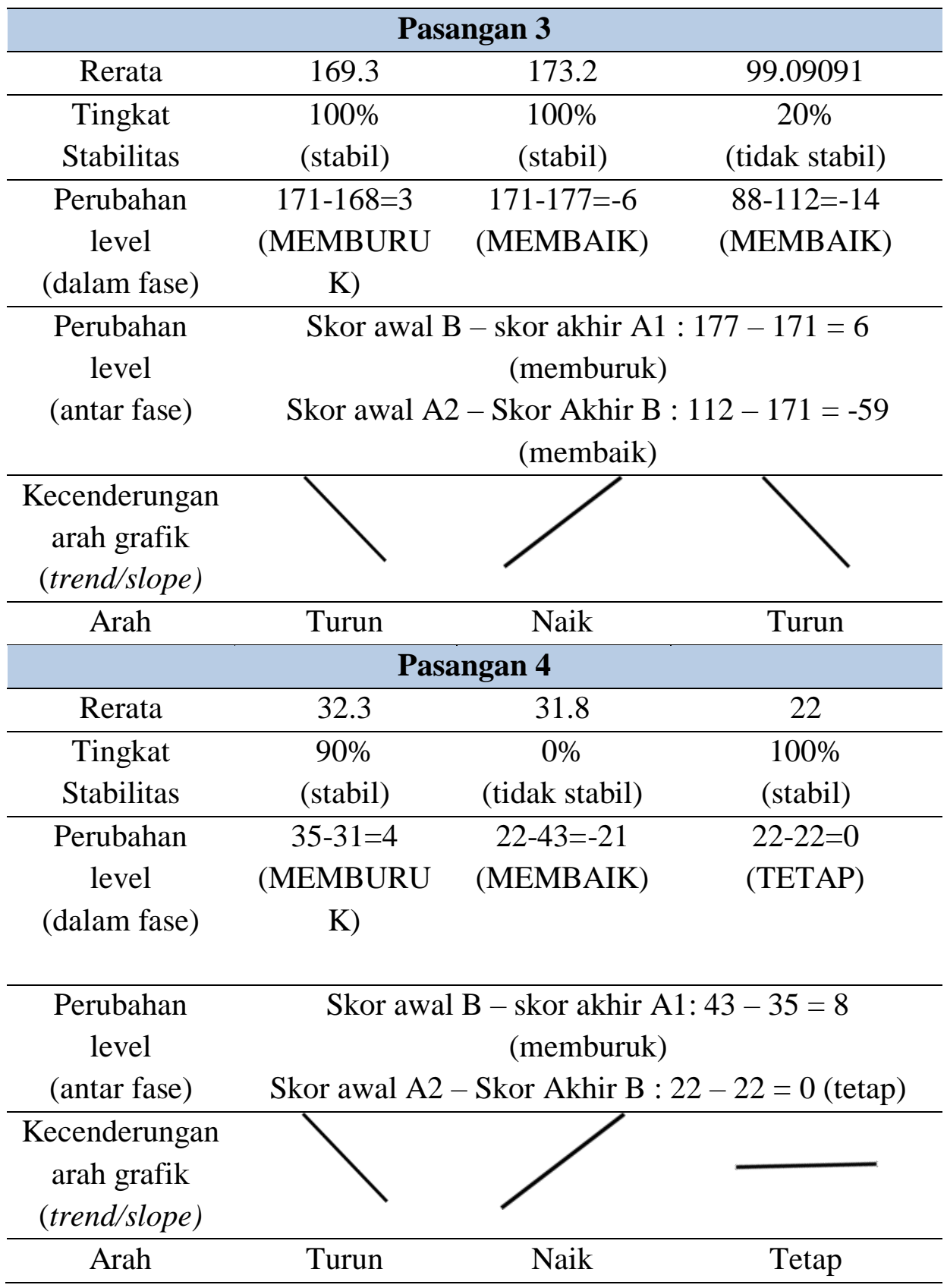

Berdasarkan hasil di atas, ditemukan bahwa pada awal pengukuran skor skala coparenting pasangan 1 dan 3, berada pada Anfusina, Volume 3, No. 1, Tahun 2020 
kategori Tinggi. Sedangkan skor skala coparenting pasangan 2 dan 4, berada pada kategori Rendah. Pada pengukuran awal, pengukuran dilakukan selama 10 hari berturut-turut sehingga kategori skor yang di dapatkan merupakan hasil akumulasi selama 10 hari. Hal ini berarti, untuk aspek coparenting cukup baik dimiliki oleh pasangan 1 serta pasangan 3. Sebaliknya, aspek coparenting pada pasangan 2 dan 4 secara kuantitatif tidak begitu baik.

Pada pengukuran kedua, terlihat bahwa adanya perubahan skor pada setiap pasangan. Pengukuran dilakukan setelah pertemuan intervensi selesai dilakukan, sehingga pada pengukuran kedua dilakukan sebanyak 7 kali. Data di fase ini menunjukkan, hanya pasangan 1 dan 3 yang secara rutin mengikuti pengukuran pada fase kedua. Sedangkan pasangan 2 dan 4, beberapa kali melewatkan pengukuran karena pada kedua pasangan ini terdapat beberapa sesi yang tidak bisa selesai dalam 1 kali pertemuan. Skor yang di dapatkan adalah pada pasangan 1 dan 3, skor coparenting stabil pada kategori Tinggi. Sedangkan skor pada pasangan 2 dan 4 skor coparenting yang mereka dapatkan berada pada kategori rendah.

Pengukuran ketiga dilakukan 1 minggu setelah terapi selesai dilakukan, pengukuran fase ini dilakukan sebanyak 10 hari berturut-turut. Sayangnya, pasangan 1 dan 3 tidak dapat mengikuti keseluruhan pengukuran dengan baik karena kesibukkan sehingga data yang di dapatkan pada kedua pasangan tidak stabil. Sebaliknya, pasangan 2 dan 4 aktif dalam melakukan pengukuran sehingga data yang di dapatkan cenderung stabil. Skor yang di dapatkan pasangan 1 dan 3 dalam aspek coparenting adalah Tinggi, sedangkan skor yang dimiliki pasangan 2 dan 4 cenderung rendah.

Dari hasil pengukuran 3 fase di atas, ditemukan bahwa pasangan 1 dan 3 memiliki skor coparenting yang tinggi sedangkan pasangan 2 dan 4 memiliki skor coparenting yang rendah. Hal ini berarti, pasangan 1 dan 3 dalam pengasuhan dikategorikan sebagai orang tua yang kompak dan saling mendukung. Keduanya selalu sejalan 
dalam bersikap, sehingga keduanya mempraktekkan gaya pengasuhan yang sama. Sebaliknya, pada pasangan 2 dan 4 dengan skor coparenting yang rendah keduanya juga memiliki kecenderung berkonflik dan berbeda dalam praktik pengasuhan

\section{Skala pengasuhan disfungsional}

Pengukuran ini dilakukan untuk melihat bentuk pengasuhan yang dilakukan oleh ke empat pasangan dalam keluarga. Secara rinci, diuraikan dalam table berikut:

\section{Tabel 3.}

Skor rerata skala pola pengasuhan disfungsional pada orangtua

\begin{tabular}{|c|c|c|c|}
\hline Partisipan & $\begin{array}{c}\text { Pretest } \\
(\text { Amatan 1) }\end{array}$ & $\begin{array}{c}\text { Post-Test } \\
\text { (Intervensi) }\end{array}$ & $\begin{array}{l}\text { Follow Up } \\
\text { (Amatan 2) }\end{array}$ \\
\hline Skor & 34.2 & 31 & 23 \\
\hline Kategori & Sedang & Sedang & Rendah \\
\hline Skor & 41.3 & 26.6 & 24.6 \\
\hline Kategori & Sedang & Sedang & Sedang \\
\hline Skor & 58.1 & 42 & 30 \\
\hline Kategori & Tinggi & Sedang & Sedang \\
\hline Skor & 41 & 25.6 & 31.5 \\
\hline Kategori & Sedang & Sedang & Sedang \\
\hline Skor & 34.6 & 31 & 23 \\
\hline Kategori & Sedang & Sedang & sedang \\
\hline Skor & 59.3 & 38 & 34 \\
\hline Kategori & Tinggi & Sedang & Sedang \\
\hline Skor & 61 & 55 & 52.5 \\
\hline Kategori & Tinggi & Sedang & Sedang \\
\hline Skor & 59.9 & 38 & 34 \\
\hline Kategori & Tinggi & Sedang & Sedang \\
\hline
\end{tabular}

Tabel di atas menunjukkan bahwa pola pengasuhan disfungsional tertinggi, dilakukan oleh pasangan 4, keduanya berada pada kategori skor Tinggi. Selanjutnya pasangan 2 dan 3 memiliki skor pengasuhan disfungsional dalam kategori sedang Anfusina, Volume 3, No. 1, Tahun 2020 
dan tinggi, keduanya terlihat memiliki perbedaan kategori skala pengasuhan disfungsional. Hal ini berarti, bahwa pada pasangan 2 dan 3 cenderung tidak sejalan dalam praktik pengasuhan. Skor pengasuhan disfungsional paling rendah, dimiliki oleh pasangan 1 keduanya sama-sama memiliki kategori skor sedang dalam skala pengasuhan disfungsional. Hal ini berarti, bahwa ke 4 pasang orangtua melakukan pola pengasuhan disfungsional pada anak.

Untuk melihat gaya pengasuhan pada masing-masing orangtua, dijelaskan pada tabel berikut:

Tabel 4.

Aspek pola pengasuhan disfungsional orangtua

\begin{tabular}{|c|c|c|c|c|}
\hline Partisipan & Aspek & $\begin{array}{l}\text { Pre- } \\
\text { test }\end{array}$ & $\begin{array}{l}\text { Post- } \\
\text { test }\end{array}$ & $\begin{array}{l}\text { Follow- } \\
\text { up }\end{array}$ \\
\hline & Permisif & 7 & 4 & 4 \\
\hline & Authoritarian & 6.8 & 8.2 & 7 \\
\hline & Verbosity & 4.6 & 8 & 3 \\
\hline & Permisif & 4.8 & 3 & 3 \\
\hline & Authoritarian & 13.5 & 9.4 & 8.4 \\
\hline & Verbosity & 6 & 3.2 & 4.1 \\
\hline & Permisif & 9.3 & 6 & 4 \\
\hline & Authoritarian & 23.5 & 16 & 11 \\
\hline & Verbosity & 2.6 & 4 & 7 \\
\hline & Permisif & 7.27 & 4 & 7 \\
\hline & Authoritarian & 13.9 & 8.6 & 11.3 \\
\hline & Verbosity & 8.9 & 3.4 & 3 \\
\hline & Permisif & 7 & 4 & 4 \\
\hline & Authoritarian & 7.8 & 9.4 & 8 \\
\hline & Verbosity & 4 & 8 & 3 \\
\hline & Permisif & 8.6 & 8.6 & 8.6 \\
\hline & Authoritarian & 16 & 11.8 & 11 \\
\hline & Verbosity & 5.8 & 2.2 & 5 \\
\hline & Permisif & 13 & 10.4 & 8.7 \\
\hline & Authoritarian & 21.3 & 15.4 & 14.5 \\
\hline & Verbosity & 9 & 0 & 0 \\
\hline & Permisif & 8.63 & 6.4 & 6 \\
\hline & Authoritarian & 16 & 11.8 & 11 \\
\hline & Verbosity & 5.8 & 2.2 & 5 \\
\hline
\end{tabular}

Tabel di atas menunjukkan bentuk pola pengasuhan yang dilakukan oleh pasangan pada anak masing-masing. Pada table 
terlihat bahwa pasangan 2, 3 dan 4 memiliki gaya pengasuhan yang sama, yaitu authoritarian. Namun pada pasangan 1, terdapat perbedaan gaya pengasuhan dimana suami menunjukkan skor pengasuhan Permisif yang tinggi sedangkan istri menunjukkan skor pengasuhan authoritarian yang tinggi. Jika dibandingkan dengan pengukuran pada skala sebelumnya, ditemukan hasil yang bertolak belakang pada pasangan 1. Dimana keduanya menunjukkan gaya pengasuhan yang berbeda, namun memiliki kategori aspek coparenting yang cukup tinggi.

\section{Hasil Kualitatif}

Sebagai penunjang pengukuran, kepada para partisipan juga dilakukan observasi dan wawancara.

Tabel 5.

Hasil observasi dan wawancara

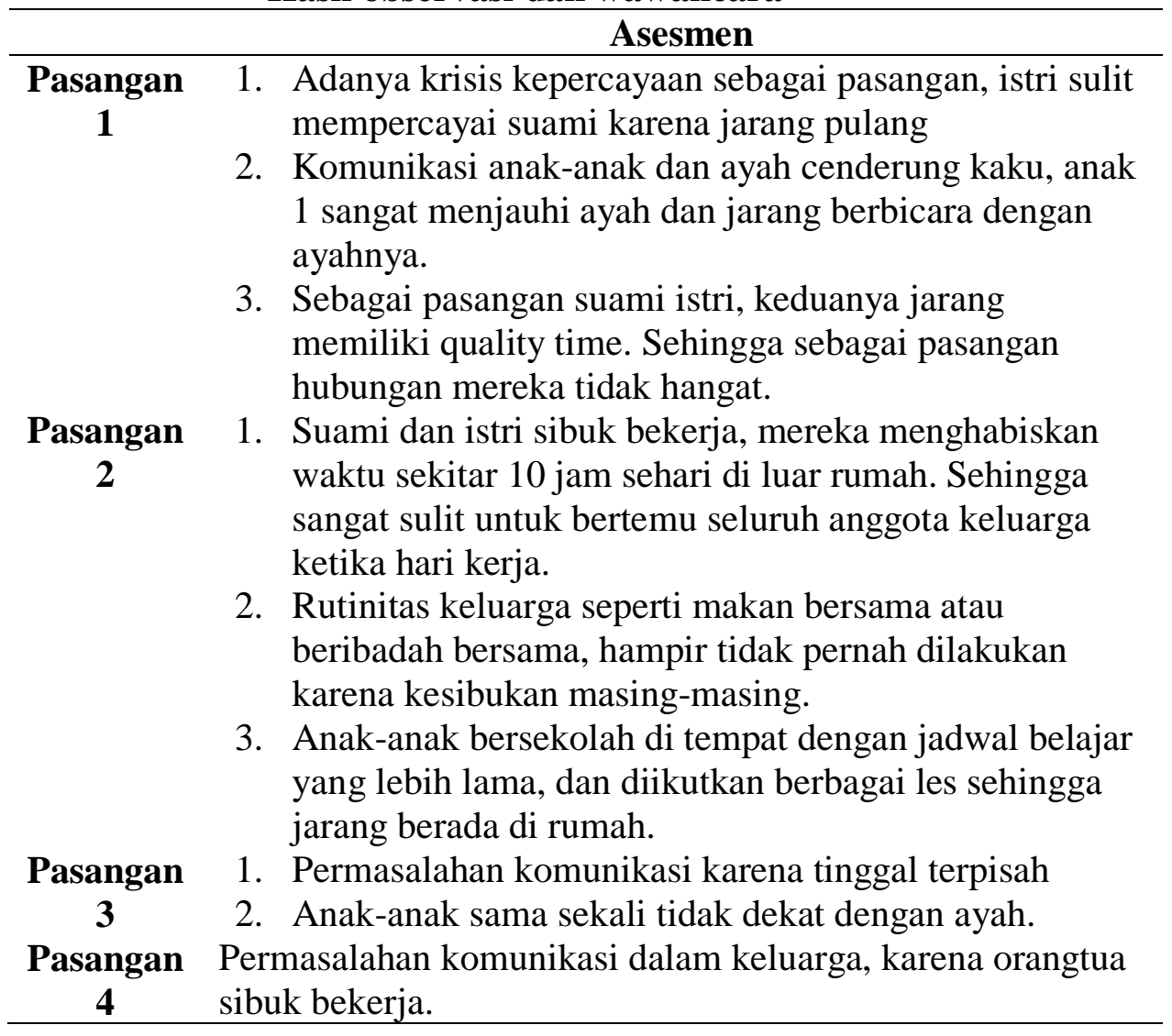




\section{Pembahasan}

Pertanyaan penelitian mendapatkan jawaban dari data yang sudah diuraikan sebelumnya diatas, bahwa terdapat pengaruh dari integrative behavioral couple therapy terhadap pola pengasuhan coparenting. Hal ini ditunjukkan dengan penurunan skor skala. Pada fase pengukuran awal seluruh partisipan mendapatkan skor rentang kategori sedang. Kategori ini kemudian berubah menjadi ringan ketika fase pengukuran kedua. Kategori ini menetap pada fase pengukuran ketiga, dimana pada masing-masing partisipan mengalami kenaikan skor. Kenaikan skor ini menunjukkan bahwa adanya perubahan dalam pola pengasuhan yang dilakukan oleh kedua pasangan.

Skor skala pola pengasuhan disfungsional pada 7 orang dari 4 pasangan mengalami penurunan dari ketiga fase pengukuran, hal ini berarti bahwa setiap orangtua mampu menerapkan prinsipprinsip dan edukasi mengenai pengasuhan yang diberikan dalam terapi. Penurunan skor skala pola pengasuhan disfungsional tidak terlepas dari kerjasama kedua orangtua sebagai pasangan, dimana jika komunikasi kedua orangtua sebagai pasangan baik maka mereka juga akan melakukan komunikasi yang baik dengan anakanak sehingga memudahkan aplikasi pola pengasuhan positif dalam keluarga.

Pernyataan tersebut diatas dikuatkan dengan penelitian sebelumnya yang menyatakan bahwa hubungan kedua orangtua yang romantis, jauh dari permasalahan serta konflik akan memunculkan pola pengasuhan positif pada anak. Tiga pasang orangtua dalam penelitian ini merubah pola komunikasi mereka yang semula kaku menjadi menambahkan beberapa panggilan kesayangan, hal ini kemudian juga dilakukan oleh anak-anak. Anak-anak yang semula tidak terbiasa mengungkapkan perasaan sayang kepada anggota keluarga lainnya, akhirnya pelan-pelan mulai mencoba mengungkapkannya kepada anggota keluarga yang lain. Sedangkan pada satu pasang orangtua yang masih berkonflik 
menunjukkan bahwa terjadi kenaikan skor, yang berarti aplikasi pola pengasuhan positif belum dilakukan dengan baik pada keluarga tersebut.

Dampak pola komunikasi yang berubah pada orangtua juga dirasakan oleh anggota keluarga lainnya, dimana hubungan antara anak dengan saudaranya juga menjadi baik. Hal ini juga menjadi salah satu faktor pendukung yang mengakibatkan perubahan dalam simtom kecemasan sosial pada remaja. Hubungan remaja yang baik dengan saudaranya, membuat remaja merasa mendapatkan dukungan sehingga lebih terbuka terhadap permasalahan yang dihadapi kepada orang lain. Penelitian sebelumnya juga menyebutkan bahwa hubungan yang berkualitas dengan saudara (baik kandung maupun saudara sambung) mampu meningkatkan psychological well-being pada usia anak hingga dewasa awal.

Temuan lainnya dalam penelitian ini mengungkapkan bahwa kepada 4 orang partisipan terdapat perbedaan pola pengasuhan yang dilakukan oleh kedua orangtua. Secara umum pada salah satu orangtua memiliki peranan sebagai sosok dominan, dikarenakan lebih banyak menghabiskan waktu dengan anak. Pernyataan tersebut dikuatkan dengan penelitian sebelumnya yang mengungkapkan bahwa semakin banyak waktu yang dihabiskan oleh orangtua dengan anak, maka akan semakin membentuk kelekatan antara orangtua dengan anaknya.

Kelekatan dengan salah satu orangtua saja membuat anak menjadi kehilangan figur orangtua yang lain, sehingga membentuk buruknya komunikasi antara anak dengan salah satu orangtua. Anak menjadi sulit untuk membentuk hubungan baik dengan lawan jenis, dan teman sebaya sehingga mengakitbatkannya menjadi individu yang kurang percaya diri dan memiliki kemampuan sosial rendah. Hal ini dikuatkan dengan penelitian sebelumnya yang menyatakan bahwa figur kedua orangtua yang sulit di dapatkan akan membuat anak kurang percaya diri dan 
memiliki kemampuan sosial yang rendah (Bynion-Teah, et al. 2017, Ooi, et al. 2017).

Satu pasangan orangtua yang memiliki konflik menemukan bahwa kedua anak cenderung bingung dalam memihak antara orangtua. Berdasarkan wawancara yang dilakukan kepada salah satu anak, disebutkan bahwa mereka sering mengalami kebingungan sehingga berdampak pada kesedihan yang dirasakan saat kedua orangtua bertengkar. Kerig, Ludlow, \& Wenar (2012) menyatakan bahwa hubungan antara individu di dalam keluarga merupakan bentuk dari berjalannya suatu sistem dalam keluarga, dimana pusat dari sistem adalah hubungan pernikahan kedua orangtua yang berdampak kepada anak.

Tidak ada permasalahan berarti selama proses intervensi, walaupun begitu terdapat beberapa kelemahan dalam penelitian ini diantaranya waktu yang dialokasikan tidak bisa diterapkan secara umum pada seluruh pasangan. Selain itu keterbatasan utama dalam penelitian ini yaitu terletak pada validitas eksternalnya dimana dalam penelitian single case, hasil penelitian tidak dapat digeneralisasikan. Faktor penyebab generalisasi yang tidak bisa dilakukan adalah perbedaan latar belakang masing-masing partisipan. Usia pernikahan dirasa perlu dipertimbangkan dalam memberikan terapi ini, penelitian terdahulu yang menyebutkan bahwa orangtua baru dengan usia pernikahan dibawah 10 tahun cenderung lebih mudah dalam mengadaptasi nilai-nilai baru yang mereka temui jika dibandingkan dengan orangtua dengan usia pernikahan di atas 10 tahun

\section{Simpulan Dan Saran}

Berdasarkan penelitian ini dapat disimpulkan bahwa integrative behavioral couple therapy terbukti mampu meningkatkan coparenting, sehingga membuat hubungan kedua orangtua. Terapi ini mampu memperbaiki hubungan antar 
pasangan sebagai orangtua dan anak, sehingga tercipta komunikasi yang aman dan attachment yang baik dalam keluarga.

Peneliti selanjutnya diharapkan mempertimbangkan usia pernikahan orangtua, urutan kelahiran anak, jenis kelamin serta hal-hal lainnya yang dirasa mempengaruhi penelitian dalam menentukan kriteria partisipan. Sehingga untuk penelitian selanjutnya dapat digeneralisasikan pada keluarga dengan latar belakang yang sama.

\section{Referensi}

American Psychiatric Assocation. 2013. Diagnostic and Statistical Manual of Mental Disorders . 5th. USA: American Psychiatric Association.

Barker, J, P Mccarthy, M Jones, and A Moran. 2011. Single-case research methods in sport and exercise psychology. New York: Routledge.

Brown, Jenny. 1999. Bowen family system theory and practice : illustration and critique. New Zealand: Australian Academic Press.

Bynion-Teah , Marie, Heidemarie Blumenthal, Sarah A Bilsky, Reene M Cloutier, and Ellen W Leen-Fledneer. 2017. "Dimensions of parenting among mothers and fathers in relation to social anxiety among female adolescent." Journal of Adolescent 60: 11-15.

Eroglu S., Toprak S., Urgan O, MD, Ozge E. Onur, MD, Arzu Denizbasi, MD, Haldun Akoglu, MD, Cigdem Ozpolat, MD, Ebru Akoglu, Md. 2012. DSM-IV diagnostic and statistical manual of mental disorder. USA: American Psychiatric Organization.

Feinberg, Mark E. 2012. "The internal structure and ecological context of coparenting: a framework for research and intervention parenting: science and practice." Parenting : science and practice 95-131. 
Fletcher, A C, J K Walls, E C Cook, K J Madison, and T H Bridges. 2009. "Parenting styles as a moderator of association between maternal disciplinary strategies and child well-being." Journal of Family (29): 1724-1744.

Flouri, Eirini, Emily Midouhas, and Martina K Narayanan. 2016. "The relationship between father involvement and child problem behaviour in intact families : a 7-year cross-lagged study." Journal of Abnormal Child Psychology 44: 10111021. doi:10.1007/s10802-015-0077-9.

Halldorsson, Brynjar, and Cathy Creswell. 2017. "Social anxiety in pre-adolescent children: what do we know about maintenance?" Behaviour research and therapy 99: 19-36.

Hewison, David, Polly Casey, and Naomi Mwamba. 2016. "The Effectiveness of Couple Therapy: Clinical Outcomes in a Naturalistic United Kingdom Setting." Psychoterapy 377387.

Hugil, Melanie, Ian Fletcher, and Katherine Berry. 2017. "Investigation of associations between attachment, parenting and schizotypy." Journal of Affective Disorders 86-94.

Jackson, C, and D M Dickinson. 2009. "Developing parenting programs to prevent child health risk behavior: a practice model." Health education research 24 (6): 1029-1042.

Kearney, Christoper A. 2005. Social anxiety and social phobia in youth : characteristic, assesment and psychological treatment. USA: Springer Science.

Kerig, Patricia K, Amanda Ludlow, and Charles Wenar. 2012. Developmental psychopatology. UK: Mc-Graw Hill.

Lavner, Justin A, Allen W Barton, and Steven R.H Beach. 2019. "Improving couples relationship functioning leads to improved coparenting : a randomized controlled trial with rural african american couples." Behavior therapy 10161029.

Lebow, Jay L. 2005. Handbook of clinical family therapy. New Jersey: John Wiley \& Son Inc. 
Lestari, Sri. 2012. Psikologi keluarga : penanaman nilai dan penanganan konflik dalam keluarga. Jakarta: Kencana.

McDaniel, Brandon T, Adam M Galovan, Jaclyn D Craven, and Michelle Drouin. 2018. "“Technoference" and implications for mothers' and fathers' couple and coparenting relationship quality." Computers in Human Behavior 303313.

Ooi, Laura L, Gabriella Nocita, Robert J Coplan, Jingjing Zhu, and Linda Rose-Krasnor. 2017. "Beyond bashful: Examining links between social anxiety and young children's socioemotional and school adjustment." Early Childhood Research Quarterly 41 (April 2016): 74-83. doi:10.1016/j.ecresq.2017.06.003.

Papalia, E D, and R T Feldman. 2014. Menyelami Perkembangan Manusia; Experience Human Development. Jakarta: Salemba Humanika.

Perone, Michael, and Daniel E Hursh. 2005. APA Handbook of behavior analysis . USA: APA.

Pudjibudojo, Jatie K, Woelan Handadari, Primatia Yogi Wulandar, Ni Putu Adelia Kesumaningsari, Yudho Bawono, Honey Wahyuni Sugiharto Elgeka, Nurul Hidayati, et al. 2019. Bunga rampai psikologi perkembangan: memahami dinamika perkembangan anak. Sidoarjo: Zifatama Jawara.

Sprenkle, Douglas H, and Fred P Piercy. 2005. Research methods in family therapy. New York: The Guilford Press.

Sugiyanto. 2009. "Manipulasi : Karakteristik Eksperimen." Buletin Psikologi, 01 01: 98-108.

Sunanto , Juang, Koji Takeuchi, and Nakata Hideo . 2005. Pengantar penelitian dengan subyek tunggal. Japan: University of Tokyo.

Supratiknya, A. 2011. Merancang program dan modul psikoedukasi. Yogyakarta: Universitas Sanata Dharma.

Tifrere, Mashonda. 2018. Blend : creating a loving family after divorce. New York: Tarcherperigee. 
Zhou, Mingming. 2016. "The roles of social anxiety, autonomy, and learning orientation in second language learning: A structural equation modeling analysis." System 63: 89-100. doi:10.1016/j.system.2016.09.001. 